\title{
Effect and analysis of phenolic compounds during somatic embryogenesis induction in Feijoa sellowiana Berg
}

\author{
E. Reis ${ }^{1,2}$, M. T. Batista ${ }^{2}$, J. M. Canhoto ${ }^{1}$ \\ ${ }^{1}$ Laboratory of Plant Biotechnology, Centre for Pharmaceutical Studies, Department of Botany, University of Coimbra, Coimbra \\ ${ }^{2}$ Laboratory of Pharmacognosy, Centre for Pharmaceutical Studies, Faculty of Pharmacy, University of Coimbra, Coimbra
}

Received 11 May 2007; Accepted 24 September 2007; Published online 30 April 2008

(C) Springer-Verlag 2008

Summary. The effect of phenolic compounds on somatic embryogenesis in Feijoa sellowiana was analysed. The results showed that caffeic acid (140-560 $\mu \mathrm{M})$ significantly increased somatic embryogenesis induction compared with the control. The presence of phloridzin, even at lower concentrations $(11.5 \mu \mathrm{M})$, or caffeic acid or phloroglucinol at concentrations greater than 140.0 and $197.5 \mu \mathrm{M}$, respectively, inhibited somatic embryo development beyond the globular stage. When somatic embryos were transferred to the germination medium, the highest rates of germination $(81.9 \%)$ were obtained with embryos induced in the presence of phloroglucinol $(79.0 \mu \mathrm{M})$. At all concentrations tested, somatic embryos induced in medium containing phloroglucinol germinated at higher rates than those induced in the presence of caffeic acid. Histological and ultrastructural studies showed that somatic embryos were formed in close association with phenolic-rich cells which, in more advanced stages of development, formed a zone isolating the embryo from the maternal tissue. A comparative analysis of total phenolic content indicated that phenolics reached a peak by the third week of culture, independently of the medium used. However, after that period, the amount of phenolic compounds was significantly higher in explants cultured in the presence of phloroglucinol than in those cultured in the control or in caffeic acidcontaining medium. Attempts to identify the type of phenolic compounds showed that flavan-3-ols and gallic acid derivatives were mainly produced in phloroglucinol-containing medium, whereas flavanones and dihydroflavonols were also present in medium containing caffeic acid. Flavones were the main phenols detected in the control. The ways in which phenolic compounds may affect somatic embryogenesis are discussed.

Keywords: Feijoa sellowiana; Germination; High-performance liquid chromatography; Microscopy; Myrtaceae; Phloroglucinol.

Abbreviation: HPLC high-performance liquid chromatography.

Correspondence: J. M. Canhoto, Departamento de Botânica, Faculdade de Ciências e Tecnologia, Universidade de Coimbra, Calçada Martim de Freitas, 3001-455 Coimbra, Portugal.

E-mail: jorgecan@ci.uc.pt

\section{Introduction}

Somatic embryogenesis has been induced in hundreds of angiosperms and gymnosperms, including a large number of woody plants (Thorpe and Stasolla 2001). The formation of somatic embryos is now recognized as a useful method of clonal propagation, but somatic embryogenesis can also be used for plant regeneration from transformed cells, artificial seed production, and for the study of plant embryogenesis (von Arnold et al. 2002). For the family Myrtaceae, somatic embryogenesis has been reported for several members of the genus Eucalyptus (Muralidharan and Mascarenhas 1995, Watt et al. 1999), as well as other species of different genera (Canhoto et al. 1999a).

Feijoa sellowiana Berg., commonly known as pineapple guava or feijoa, is a woody subtropical myrtaceous plant native to South America that has spread all over the world as an ornamental tree (Canhoto and Cruz 1996a). Nowadays, feijoa is mainly grown for the quality of its fruits, New Zealand being the main producer and exporter (Canhoto and Cruz 1996a).

Somatic embryogenesis in feijoa was first achieved by our group (Cruz et al. 1990). Later work optimized the protocol for somatic embryogenesis induction (Canhoto and Cruz 1994) and showed the precise origin of somatic embryo formation, as well as the cytological and histological modifications occurring in cotyledons during somatic embryo differentiation (Canhoto and Cruz 1996b, Canhoto et al. 1996). Further studies of somatic embryogenesis in this plant showed the potential of floral explants for somatic embryo formation (Stefanello et al. 2005) and the effectiveness of different nitrogen sources in the induction process (Dal Vesco and Guerra 2001). However, as in 
most of the species in which somatic embryogenesis has been induced, the factors controlling somatic embryo formation and embryo development are still poorly understood.

Phenolic compounds constitute a wide range of plant substances which all possess an aromatic ring bearing one or more hydroxyl groups (Harborne 1998). They are normally viewed as deleterious compounds during in vitro culture, since their exudation and oxidation negatively affect the explants, causing browning and necrosis, especially when mature explants of woody plants are used (Warrag et al. 1990, Benson 2000, Martin and Madassery 2005). However, a more detailed analysis of the literature shows that, in several cases, phenolic compounds seem to be essential for the control of some morphogenic processes occurring in vitro, indicating that their role is far from being understood. Examples of the positive effect of phenolic compounds on morphogenic processes occurring in vitro are the stimulation of root formation (Mato et al. 1988, Berthon et al. 1993) and elongation (Ramírez-Malagón et al. 1997), shoot proliferation (Sarkar and Naik 2000), organogenesis (Lee and Skoog 1965, Lorenzo et al. 2001), androgenesis (Delalonde et al. 1996), and somatic embryogenesis (Hanower and Hanower 1984, Cvikrová et al. 1998, Cvikrová and Hrubcová 1999). Previous studies of feijoa (Canhoto and Cruz 1996b, Cangahuala-Inocente et al. 2004) and other woody species, such as myrtle (Canhoto et al. 1999b), carob (Canhoto et al. 2006), and bay laurel (Canhoto et al. 1999c), carried out in our laboratory have shown that early stages of somatic embryo differentiation are often associated with phenolic-rich cells. Considering these observations and the above-mentioned references, the aim of this work was to assess the effect of phenolic compounds on somatic embryogenesis induction in feijoa and the qualitative and quantitative variations in phenolic biosynthesis during the embryogenic process.

\section{Material and methods}

\section{Plant material}

Fruits were collected from plants growing at the Botanical Garden of the University of Coimbra during the months of September and October. Seeds were excised and surface sterilized for $15 \mathrm{~min}$ in a $7.5 \%$ calcium hypochlorite solution.

\section{Somatic embryogenesis induction and germination}

For somatic embryogenesis induction, whole intact cotyledonary zygotic embryos were isolated and cultured in the induction medium, which consisted of MS medium (Murashige and Skoog 1962) containing 4.5 $\mu \mathrm{M}$ 2,4-dichlorophenoxyacetic acid and $0.27 \mathrm{M}$ sucrose. The cultures were incubated at $25 \pm 1{ }^{\circ} \mathrm{C}$ in the dark and the percentage of explants forming somatic embryos was evaluated after 2.5 months of incubation. A more detailed description of this methodology was given elsewhere (Cruz et al. 1990, Canhoto and Cruz 1994). The effects of three phenolic compounds, phloroglucinol, a simple phenol (7.9 to $1264.0 \mu \mathrm{M})$, caffeic acid, a phenolic acid (5.6 to $896.0 \mu \mathrm{M}$ ), and phloridzin, a dihydrochalcone $(2.3$ to $368.0 \mu \mathrm{M})$, on somatic embryogenesis induction were tested, and the results were compared with those obtained in induction medium without phenolic compounds. Each treatment consisted of three replicates of 15 to 20 zygotic embryos.

Morphologically normal cotyledonary embryos were used in the germination assays. Somatic embryos were removed from the mother tissue and cultured in a modified MS medium containing $0.03 \mathrm{M}$ sucrose and with the major salts reduced to half strength. The medium was supplemented with $5.7 \mu \mathrm{M}$ gibberellic acid and $2.3 \mu \mathrm{M}$ kinetin. Somatic embryos originated in the control (induction medium without phenols) and in media containing 7.9 to $197.5 \mu \mathrm{M}$ of phloroglucinol or 5.6 to $140.0 \mu \mathrm{M}$ caffeic acid were tested for somatic embryo germination. The results were obtained after 7 weeks of culture at a photoperiod of $14 \mathrm{~h}$ light $\left(15-20 \mu \mathrm{mol} / \mathrm{m}^{2} \mathrm{~s}\right.$ photosynthetically active radiation provided by cool white fluorescent lamps) and $10 \mathrm{~h}$ dark, and each treatment consisted of three replicates of 20 to 25 somatic embryos. Embryos in which the cotyledons had turned green and the root had developed were considered germinated. For statistical analysis, all quantitative data expressed as percentages were first submitted to arcsine transformation and the means were corrected for the bias before a new conversion of the means and standard error back into percentages (Zar 1996). Statistical analysis was performed by an analysis of variance (ANOVA) by Statgraphics 7.0 and the significantly different means were identified by the Tukey test $(\mathrm{P}=0.05)$.

\section{Histological and ultrastructural studies}

For histological studies, sectioned cotyledons from noncultured embryos and from embryos cultured for 5, 7, 10, 14, 21, and 28 days on the induction medium were fixed for $2 \mathrm{~h}$ in a solution consisting of $2.5 \%$ (w/w) glutaraldehyde and $0.2 \mathrm{M}$ sucrose prepared with $0.1 \mathrm{M}$ phosphate buffer, $\mathrm{pH} 7.0$, and postfixed at room temperature for $1 \mathrm{~h}$ in $1 \%(\mathrm{w} / \mathrm{v})$ osmium tetroxide solution prepared with the same buffer. Samples were thoroughly dehydrated in an ethanol series (20, 40, 60, 80, 95, and $100 \%, v / v)$ and embedded in Spurr resin. Sections (1-2 $\mu \mathrm{m}$ thick) were made with glass knives on an LKB Ultratome III and stained with $0.2 \%$ (w/v) toluidine blue.

Material for scanning electron microscopy and transmission electron microscopy observations was prepared using the fixation procedure adopted for histological studies. Ultrathin sections were made on an LKB ultramicrotome with a diamond knife and collected on uncoated copper grids. Sections were conventionally contrasted with uranyl acetate and lead citrate for 15 and $10 \mathrm{~min}$, respectively, and observed under a Siemens Elmiskop 101 transmission electron microscope at $80 \mathrm{kV}$. For scanning electron microscopy examinations, the samples were criticalpoint dried with carbon dioxide as the transition fluid and coated with gold. The specimens were mounted on aluminium stubs and examined with a JEOL JSM-T330 scanning electron microscope operating at $20 \mathrm{kV}$. A more detailed description of these procedures has been provided by Canhoto et al. (1996).

\section{Extraction and quantitative analysis of total phenolic compounds}

Total phenolics were estimated by a modified version of the FolinCiocalteu method (Folin and Ciocalteu 1927) described by Wang et al. (1997). Briefly, noncultured zygotic embryos and explants cultured for 1 to 5 weeks in the control (induction medium) or in the induction medium supplemented with $79.0 \mu \mathrm{M}$ phloroglucinol or $56.0 \mu \mathrm{M}$ caffeic acid were transferred to liquid nitrogen and ground, and the phenolics were extracted with methanol ( $2.5 \mathrm{ml}$ of methanol to $100 \mathrm{mg}$ of tissue) in a blender. After centrifugation at $3000 \mathrm{rpm}\left(1360 \mathrm{~g} 10 \mathrm{~min}, 4^{\circ} \mathrm{C}\right)$, the su- 
pernatant was collected and the extraction process was repeated once more. Subsequently, the methanolic extracts were concentrated under nitrogen flow to a volume of $1 \mathrm{ml}$. Sample aliquots were put in volumetric flasks (volume, $10 \mathrm{ml}$ ) and concentrated to dryness. The residues were dissolved with $70 \%$ aqueous acetone $(100 \mu \mathrm{l})$ and ultrapure water $(1.9 \mathrm{ml})$. Folin-Ciocalteu reagent $(1 \mathrm{ml})$ was added and swirled for $1 \mathrm{~min}$. A solution of $20 \%$ (w/v) aqueous sodium carbonate $(5 \mathrm{ml})$ was added and made up to $10 \mathrm{ml}$ with ultrapure water. The flasks were stopped and mixed by inverting several times for $1 \mathrm{~min}$. After $20 \mathrm{~min}$, the absorbance of the solutions was measured at 700 and $735 \mathrm{~nm}$ in a Hitachi U-2000 spectrophotometer and the results were expressed as grams of gallic acid equivalents per $1 \mathrm{~g}$ of fresh material. All samples were analysed in triplicate on the basis of the standard curve $(\mathrm{y}=1.237922 \mathrm{x}$ $+0.079362, r=0.99)$. Statistical analysis was performed by ANOVA (Statgraphics 7.0) and the significantly different values were identified by the Tukey test $(\mathrm{P}=0.05)$.

\section{High-performance liquid chromatography analysis}

All extracts $(20 \mu 1)$ were injected into a Gilson high-performance liquid chromatography (HPLC) system equipped with a diode-array detector (DAD). The studies were carried out on a Spherisorb S5 ODS-2 column (length, $250 \mathrm{~mm}$; inner diameter, $4.6 \mathrm{~mm}$; particle size, $5 \mu \mathrm{m}$; Waters) and a Nucleosil guard cartridge $\mathrm{C} 18$ (length, $30 \mathrm{~mm}$; inner diameter, $4 \mathrm{~mm}$; particle size, $5 \mu \mathrm{m}$; Macherey-Nagel) at $25^{\circ} \mathrm{C}$. A mobile phase constituted by $5 \%(\mathrm{v} / \mathrm{v})$ aqueous formic acid and methanol was used. For the indicated periods of the $60 \mathrm{~min}$ assay, methanol was used with a discontinuous gradient of $5-15 \% \quad(0-10 \mathrm{~min}), 15-30 \% \quad(10-15 \mathrm{~min})$, $30-35 \%$ (15-25 $\mathrm{min}), 35-50 \%$ (25-35 $\mathrm{min}$ ), and 50-80\% (35-40 $\mathrm{min}$ ), followed by an isocratic elution for $20 \mathrm{~min}$, at a flow rate of $1 \mathrm{ml} / \mathrm{min}$. Chromatographic profiles were recorded at 280 and $320 \mathrm{~nm}$. Data treatment was carried out by the Unipoint 2.10 software.

\section{Results}

\section{Effect of phenolic compounds on somatic embryogenesis induction and somatic embryo conversion}

The effect of exogenous phenolic compounds on somatic embryogenesis induction in feijoa was analysed through the inclusion of phenols in the induction medium. The results showed that the presence of caffeic acid at concentrations between 140.0 and $560.0 \mu \mathrm{M}$ significantly increased somatic embryo formation over the control, with $100 \%$ of the explants producing somatic embryos. Similar results were achieved when $197.5 \mu \mathrm{M}$ phloroglucinol was tested, although in this case the frequency of induction did not reach $100 \%$ (Table 1). The data clearly show that the inclusion of phenolic compounds in the induction medium strongly inhibited somatic embryo formation, especially at concentrations greater than $197.5 \mu \mathrm{M}$ phloroglucinol and $57.5 \mu \mathrm{M}$ phloridzin (Table 1). In the case of caffeic acid, the frequencies of induction remained high even at the maximum concentrations used (Table 1). Somatic embryos formed in the presence of phloridzin only occasionally passed the globular stage of development (Fig. 1A). More advanced stages of somatic embryo development
Table 1. Effect of different phenolic compounds on somatic embryogenesis induction

\begin{tabular}{|c|c|c|}
\hline $\begin{array}{l}\text { Phenolic compound } \\
(\mu \mathrm{M}) \text { in induction } \\
\text { medium }\end{array}$ & $\begin{array}{l}\text { Nr. of } \\
\text { explants } \\
\text { cultured }\end{array}$ & $\begin{array}{l}\text { \% explants with } \\
\text { embryogenesis } \\
\text { induced }^{\mathrm{a}}\end{array}$ \\
\hline None & 57 & $84.2 \pm 3.1 b, c$ \\
\hline \multicolumn{3}{|l|}{ Phloroglucinol } \\
\hline 7.9 & 48 & $87.5 \pm 7.2 \mathrm{~b}, \mathrm{c}$ \\
\hline 39.5 & 48 & $75.0 \pm 3.6 \mathrm{c}, \mathrm{d}$ \\
\hline 79.0 & 40 & $72.5 \pm 7.8 \mathrm{c}, \mathrm{d}$ \\
\hline 197.5 & 38 & $94.7 \pm 5.6 \mathrm{a}, \mathrm{b}$ \\
\hline 395.0 & 48 & $43.8 \pm 1.8 \mathrm{~g}$ \\
\hline 790.0 & 39 & $66.6 \pm 4.1 \mathrm{~d}$ \\
\hline 1264.0 & 42 & $23.8 \pm 1.4 \mathrm{~h}$ \\
\hline \multicolumn{3}{|l|}{ Caffeic acid } \\
\hline 5.6 & 51 & $88.2 \pm 4.6 \mathrm{~b}$ \\
\hline 28.0 & 42 & $92.8 \pm 9.2 b$ \\
\hline 56.0 & 51 & $88.2 \pm 6.9 \mathrm{~b}$ \\
\hline 140.0 & 43 & $100.0 \mathrm{a}$ \\
\hline 280.0 & 46 & $100.0 \mathrm{a}$ \\
\hline 560.0 & 39 & $100.0 \mathrm{a}$ \\
\hline 896.0 & 42 & $92.9 \pm 6.3 b$ \\
\hline \multicolumn{3}{|l|}{ Phloridizin } \\
\hline 2.3 & 45 & $91.1 \pm 7.1 \mathrm{~b}$ \\
\hline 11.5 & 42 & $92.9 \pm 7.1 \mathrm{~b}$ \\
\hline 23.0 & 44 & $88.6 \pm 2.0 \mathrm{~b}$ \\
\hline 57.5 & 49 & $93.9 \pm 3.4 \mathrm{~b}$ \\
\hline 115.0 & 48 & $50.0 \pm 5.6 \mathrm{f}$ \\
\hline 230.0 & 49 & $57.1 \pm 0.5 \mathrm{e}$ \\
\hline 368.0 & 56 & $7.1 \pm 2 \mathrm{i}$ \\
\hline
\end{tabular}

${ }^{a}$ Each value is the mean with standard error of three replicates. Values followed by the same letter are not significantly different (Tukey test, $\mathrm{P}<0.05)$

(torpedo and cotyledonary) were only observed at the lowest concentration used $(2.3 \mu \mathrm{M})$. In contrast, somatic embryos formed on media containing up to $197.5 \mu \mathrm{M}$ phloroglucinol or $140 \mu \mathrm{M}$ caffeic acid were morphologically identical to those developing in the control, and most of them passed through the different morphological phases resembling common aspects of zygotic embryogenesis (Fig. 1B, C). However, at higher concentrations of these phenols, somatic embryos also failed to reach more advanced stages of development, as with phloridzin.

Cotyledonary somatic embryos (Fig. 1D, E) developed on media containing phloroglucinol (7.9 to $197.5 \mu \mathrm{M}$ ) or caffeic acid (5.6 to $140.0 \mu \mathrm{M}$ ) were transferred to the germination medium in order to determine whether the induction media could affect somatic embryo germination. Somatic embryos formed on media supplemented with phloridzin or with phloroglucinol or caffeic acid at concentrations greater than $197.5 \mu \mathrm{M}$ or $140 \mu \mathrm{M}$, respectively, were not used since, as already mentioned, they did 

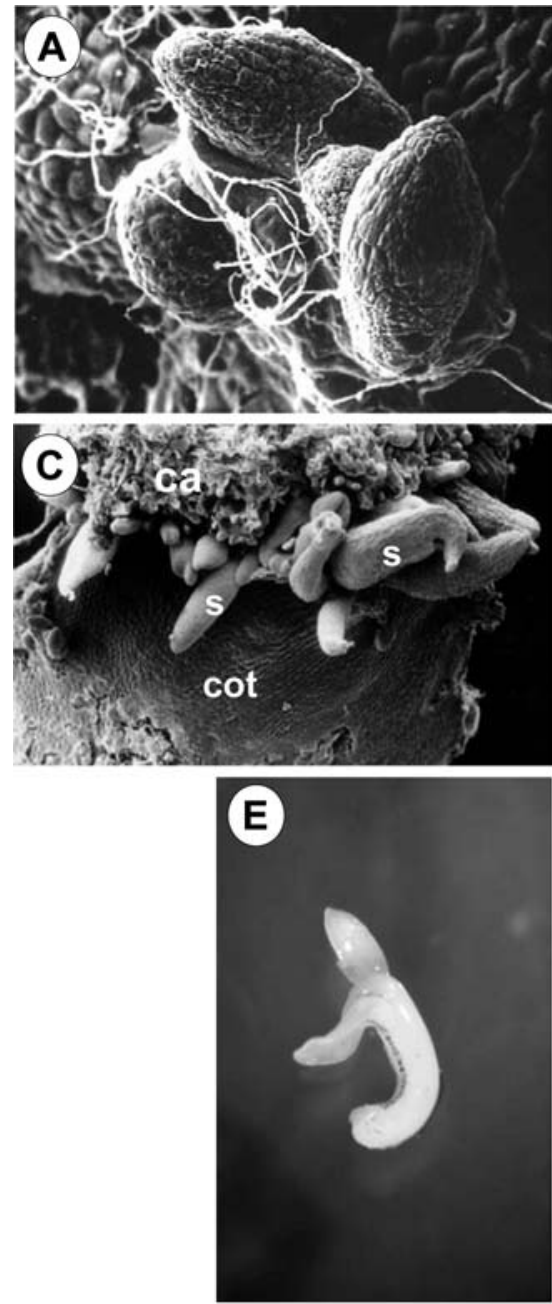
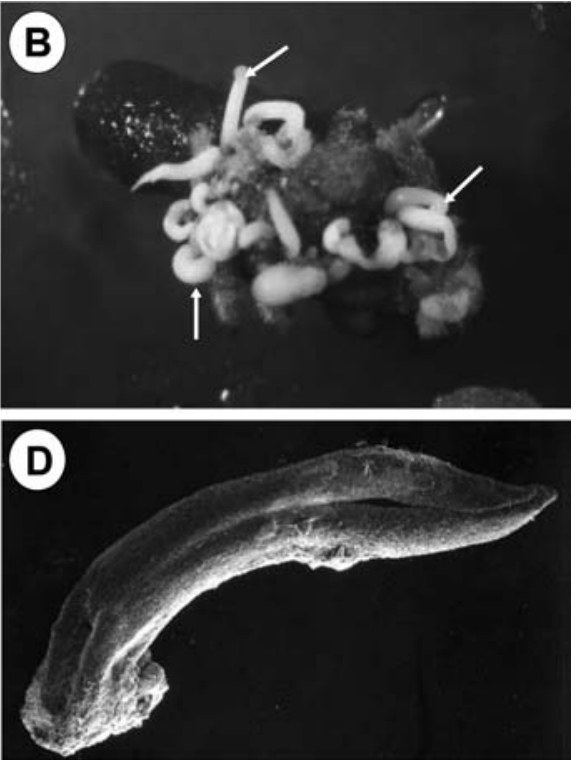

F

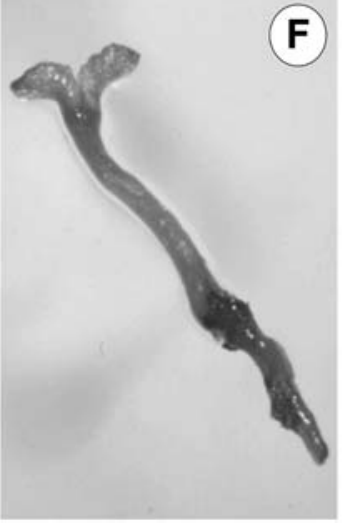

Fig. 1 A-F. Morphological aspects of somatic embryogenesis induction and somatic embryo germination. A Globular somatic embryos on a medium containing $23.0 \mu \mathrm{M}$ phloridzin $(\times 85)$. B Somatic embryos (arrows) at different stages of development on medium containing $79.0 \mu \mathrm{M}$ phloroglucinol $(\times 8)$. C Several somatic embryos $(s)$ and a callus $(\mathrm{ca})$ developing from a cotyledon (cot) of a zygotic embryo ( $\times 63)$. D Scanning electron microscopy image of a cotyledonary somatic embryo $(\times 65)$. E Somatic embryo produced on medium containing $56.0 \mu \mathrm{M}$ caffeic acid just before inoculation into the germination medium $(\times 13.5)$. F Germinated embryo $(\times 8)$
Table 2. Somatic embryo germination on MS medium containing gibberellic acid and kinetin ${ }^{\mathrm{a}}$

\begin{tabular}{lll}
\hline $\begin{array}{l}\text { Phenolic compound } \\
(\mu \mathrm{M}) \text { in germination } \\
\text { medium }\end{array}$ & $\begin{array}{l}\text { Nr. of } \\
\text { embryos } \\
\text { cultured }\end{array}$ & $\begin{array}{l}\text { \% embryos } \\
\text { germinated }^{\mathrm{b}}\end{array}$ \\
\hline $\begin{array}{l}\text { None } \\
\text { Phloroglucinol }\end{array}$ & 70 & $41.4 \pm 1.7 \mathrm{~d}$ \\
7.9 & 67 & $58.2 \pm 3.1 \mathrm{c}$ \\
39.5 & 75 & $69.3 \pm 3.7 \mathrm{~b}$ \\
79.0 & 72 & $81.9 \pm 5.1 \mathrm{a}$ \\
197.5 & 67 & $61.2 \pm 1.4 \mathrm{c}$ \\
Caffeic acid & & $24.6 \pm 2.6 \mathrm{f}$ \\
5.6 & 69 & $33.3 \pm 3.6 \mathrm{e}$ \\
28.0 & 69 & $25.0 \pm 1.2 \mathrm{f}$ \\
56.0 & 72 & $9.3 \pm 3.5 \mathrm{~g}$ \\
140.0 & 75 & \\
\hline
\end{tabular}

a Somatic embryos were generated on media containing caffeic acid or phloroglucinol and compared with the control

${ }^{\mathrm{b}}$ Each value is the mean with standard error of three replicates. Values followed by the same letter are not significantly different (Tukey test, $\mathrm{P}<0.05)$ not reach the appropriate stage of development. The results showed that the highest number of germinated embryos (Fig. 1F) was obtained when $79 \mu \mathrm{M}$ phloroglucinol was used (Table 2), and this value was significantly different from all other tested media. The results also indicated that, at the same phenol concentrations, somatic embryos germinated at higher rates when they were produced on medium containing phloroglucinol than on medium containing caffeic acid.

\section{Microscopy studies}

Histological analysis during somatic embryo development showed that somatic embryos were generally formed in association with phenol-rich cells (Fig. 2A). This association was found both in the control and in explants cultured in the presence of the different phenols and could be observed from the early stages of somatic embryo differentiation (one and two weeks of culture), where few-celled 

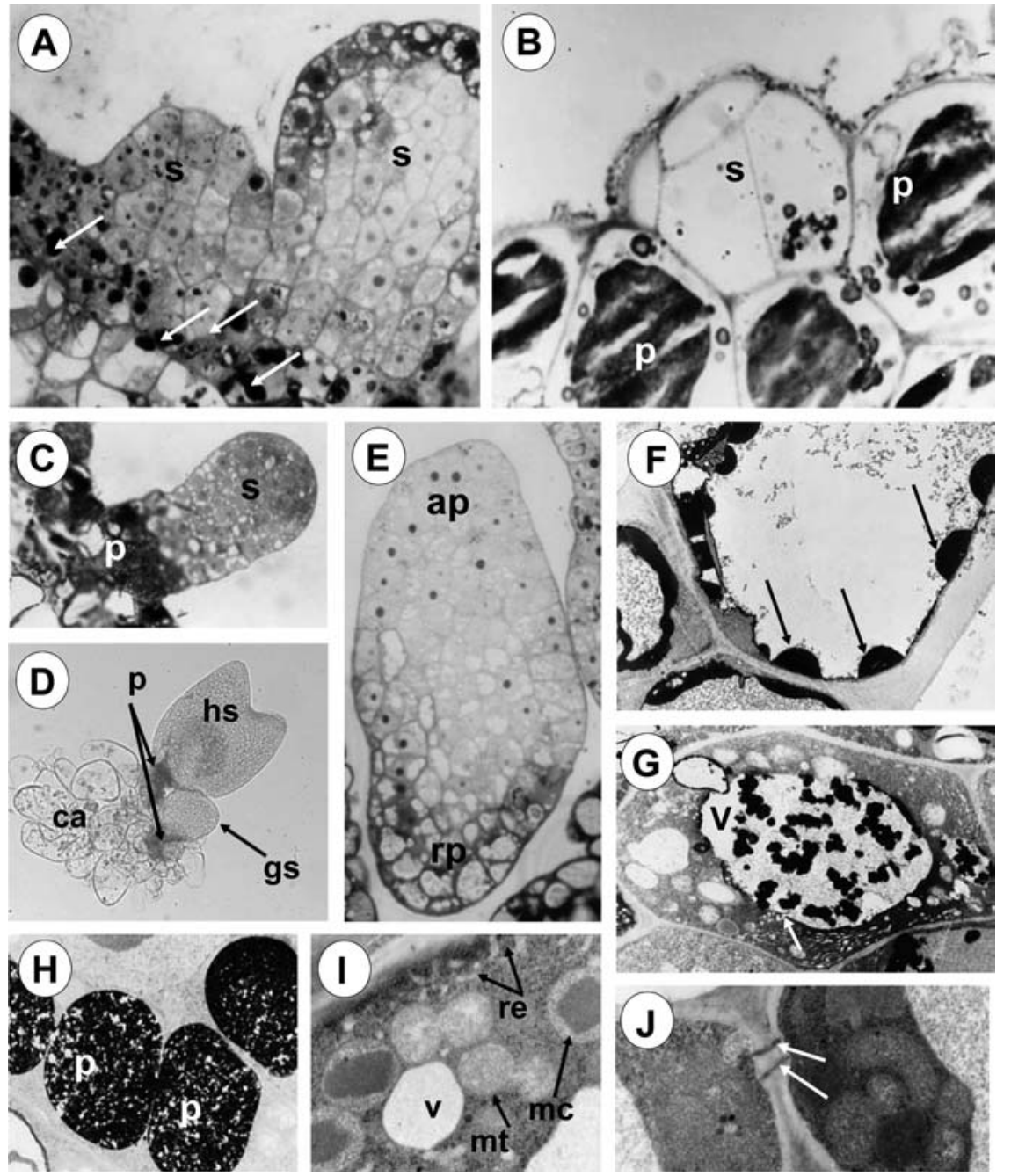

Fig. 2 A-J. Histological and ultrastructural analysis of somatic embryo formation. A Section of an embryogenic cotyledon showing two developing somatic embryos $(s)$. Note the accumulation of phenols (arrows) mainly at the base of the embryos $(\times 620)$. B Few-celled somatic embryo $(s)$ surrounded by phenol-rich cells $(p)(\times 1900)$. C Globular somatic embryo $(s)$ connected to the mother tissue by a zone $(p)$ of cells in which phenolic compounds are accumulated $(\times 580)$. D Heartshaped $(h s)$ and globular $(g s)$ embryos linked to callus tissue $(\mathrm{ca}$ ) through a zone of phenolic cells $(p)(\times 210)$. E Section of a somatic embryo showing two distinct zones: apical zone $(a p)$ and root pole $(r p)(\times 620)$. F Section of a nonembryogenic cell showing the accumulation of phenolic compounds (arrows) near the tonoplast $(\times 14100)$. G Cell of the phenolic zone indicated in $\mathbf{D}$ showing phenolic compounds randomly distributed in the vacuole $(v)$. Cytoplasmic vesicles presumably fusing to the vacuole can be seen (arrow) $(\times 10800)$. $\mathbf{H}$ As in $\mathbf{G}$, but showing the vacuoles completely filled with phenolic compounds $(p)(\times 14100)$. I Section of a cell from the phenolic zone showing microbodies with a crystalloid inclusion $(m c)$, poorly differentiated mitochondria $(m t)$, and profiles of rough endoplasmic reticulum $(r e)(\times 23500)$. J Two adjacent cells of a somatic embryo showing two plasmodesmata (arrows) $(\times 35000)$ embryos were surrounded by cells rich in phenols (Fig. 2B). In more advanced stages of somatic embryo development, from the third week of culture, somatic embryos were separated from the supporting tissue by a zone of phenol-rich cells that formed a kind of barrier making it easy to detach the embryos from the mother tissue (Fig. 2C, D). At this time, somatic embryos displayed a strong polarity, showing a root pole, where more vacuolated cells were present, and an apical pole containing a dense cytoplasm, a large nucleus, and a prominent nucleolus (Fig. 2E). By the second week of culture, cells of the separation zone between the developing embryos and the mother tissue became highly vacuolated and started to accumulate phenols that could be seen initially as electrondense zones near the tonoplast (Fig. 2F) or randomly scattered in the vacuoles (Fig. 2G). In later stages, phenol accumulation could be seen as dark zones that completely filled the vacuoles (Fig. 2H). Phenol-accumulating cells were also characterized by the presence of microbodies possessing a granular matrix and a crystalloid diamondshaped inclusion (Fig. 2I). A few starch grains, poorly differentiated mitochondria, and large areas of endoplasmic reticulum were also frequently observed (Fig. 2I). Vesicles fusing with the tonoplast were normally found in cells of the separation zone (Fig. 2G), suggesting a mechanism of discharge of vesicular contents into the vacuoles. In contrast to the cells of the developing embryos (Fig. 2J), plasmodesmata were never found in the thick cell walls of the separation zone.

\section{Phenolic compound analysis}

Since the highest number of plantlets was obtained from embryos developed in medium containing $79.0 \mu \mathrm{M}$ phloroglucinol, we decided to compare the evolution of the total phenol content in the explants cultured in the 
Table 3. Time-course analysis of total phenolic compounds in explants cultured on the embryogenic induction medium or in media containing phloroglucinol or caffeic acid

\begin{tabular}{llll}
\hline $\begin{array}{l}\text { Weeks of } \\
\text { culture }\end{array}$ & \multicolumn{2}{l}{ Total phenolics content in explants cultured: } \\
\cline { 2 - 4 } & $\begin{array}{l}\text { Without } \\
\text { phenolics }\end{array}$ & $\begin{array}{l}\text { With } 79.0 \mu \mathrm{M} \\
\text { phloroglucinol }\end{array}$ & $\begin{array}{l}\text { With } 56.0 \mu \mathrm{M} \\
\text { caffeic acid }\end{array}$ \\
\hline 1 & $0.1 \pm 0.015 \mathrm{~g}$ & $0.9 \pm 0.05 \mathrm{e}$ & $1.1 \pm 0.09 \mathrm{~d}, \mathrm{e}$ \\
2 & $1.5 \pm 0.01 \mathrm{c}$ & $1.3 \pm 0.11 \mathrm{c}$ & $1.2 \pm 0.14 \mathrm{c}, \mathrm{d}$ \\
3 & $2.6 \pm 0.06 \mathrm{a}$ & $2.4 \pm 0.14 \mathrm{a}$ & $2.0 \pm 0.09 \mathrm{~b}$ \\
4 & $0.3 \pm 0.06 \mathrm{f}$ & $2.3 \pm 0.07 \mathrm{a}$ & $1.2 \pm 0.05 \mathrm{c}, \mathrm{d}$ \\
5 & $0.3 \pm 0.05 \mathrm{f}$ & $2.0 \pm 0.09 \mathrm{~b}$ & $1.3 \pm 0.12 \mathrm{c}$ \\
\hline
\end{tabular}

${ }^{\text {a }}$ Results expressed in milligrams of gallic acid equivalent per gram of fresh weight. The initial amount of total phenolic compounds in the explants was $0.017 \pm 0.003 \mathrm{mg}$ of gallic acid equivalent per $\mathrm{g}$ of fresh weight. Each value is the mean with standard error of three replicates. Values followed by the same letter are not significantly different (Tukey test, $\mathrm{P}<0.05)$

presence of phloroglucinol with those cultured in the control and in medium containing $56.0 \mu \mathrm{M}$ caffeic acid. The results showed that the phenolic content of the initial explants (mature zygotic embryos) was quite low (Table 3). By the first week of culture, the control explants had a significantly lower phenol content than those cultured in the presence of phloroglucinol. Two weeks later, by the third week of culture, the amount of total phenols reached a maximum in both conditions with no statistically significant differences between them. This was also the time at which the first globular somatic embryos started to appear in the explants. After this period (fourth and fifth weeks), the amount of phenols remained high in explants cultured with phloroglucinol, whereas the phenol concentration dropped considerably in the control explants (Table 3). When the levels of endogenous phenolics in explants cultured in the presence of $79.0 \mu \mathrm{M}$ phloroglucinol or $56.0 \mu \mathrm{M}$ caffeic acid were compared, statistically significant differences were not detectable until the third week of culture, when explants cultured in the phloroglucinolcontaining medium displayed higher levels (Table 3). Similar differences between the two media were also observed in the following weeks (Table 3).

Assays to analyse the type of phenols produced by explants cultured in the control (induction medium) and in media containing $79.0 \mu \mathrm{M}$ phloroglucinol or $56.0 \mu \mathrm{M}$ caffeic acid were carried out using a HPLC diode-array detector. Three weeks after culture initiation, the phenolic compounds produced differed qualitatively and/or quantitatively, depending on the culture medium used (Fig. 3). Under the conditions assessed, flavones (peaks 1, 3, and 5), a chalcone (peak 6), flavan-3-ols and gallic acid deriv-
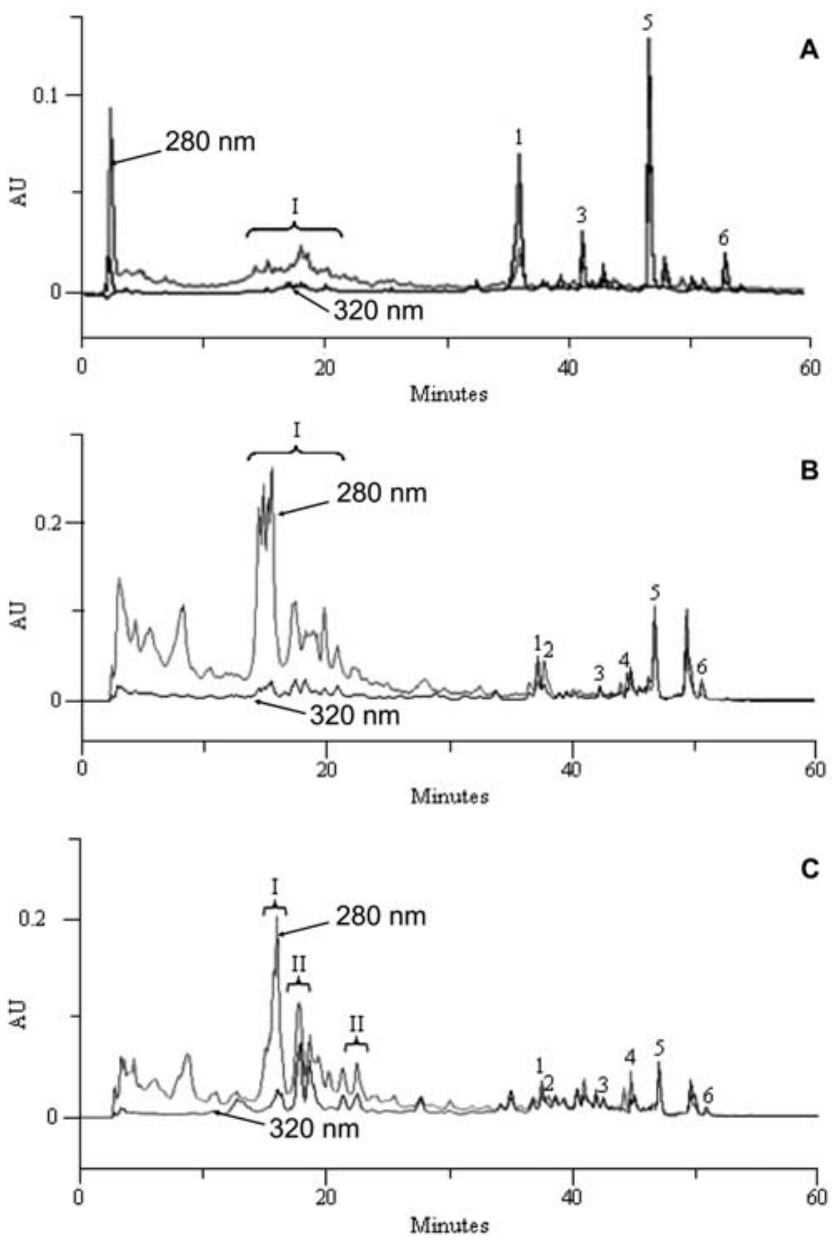

Fig. 3. HPLC diode-array detector profiles of methanolic extracts from embryos cultivated for three weeks in the induction medium (A) or in the induction medium supplemented with $79.0 \mu \mathrm{M}$ phloroglucinol (B) or $56.0 \mu \mathrm{M}$ caffeic acid (C). Peaks 1, 3, and 5, flavones. Peak 2, ellagic acid. Peak 4, ellagic acid derivatives. Peak 6, chalcone. Zone I, flavan-3ols and gallic acid derivatives. Zones II, flavanones and dihydroflavonol derivatives

atives (I), and ellagic acid and its derivatives (peaks 2 and 4 , respectively) were identified. Flavones were the major phenolic metabolites produced in the induction medium, while the compounds of zone I were mainly synthesized in medium supplemented with phloroglucinol or caffeic acid (Fig. 3). HPLC chromatograms obtained from the phenol-containing media extracts showed the presence of epigallocatechin $\left(R_{t}=16.29 \mathrm{~min}\right)$ and epigallocatechin gallate $\left(\mathrm{R}_{\mathrm{t}}=19.34 \mathrm{~min}\right)$, which were tentatively identified by comparing their UV spectra and retention times with authentic samples. In the caffeic acid medium extract, significant amounts of flavanones and/or dihydroflavonol derivatives were also produced (Fig. 3, zones II), as indicated by their UV spectra. 


\section{Discussion}

The results presented in this work indicate that exogenous phenolic compounds added to the embryogenic induction medium affect both the somatic embryogenesis induction and the further somatic embryo germination. Furthermore, microscopic analysis showed a strong relationship between somatic embryo development and phenolic-rich cells. Other important findings of this work were that the levels of total phenolics changed during the embryogenic process and that the inclusion of exogenous phenols in the induction medium modified the type of phenolic compounds present in the embryogenic explants and their relative proportions.

Phenolic compounds are usually seen as deleterious compounds for in vitro propagation, especially when woody plants are used (Pan and van Staden 1998, Arezki et al. 2001, Tang and Newton 2004). However, an increasing number of data seem to indicate that the role of phenolic compounds in in vitro cultures should be analysed more carefully since, in some systems, phenols promote in vitro morphogenic processes. For example, the positive effects of phenols on root formation (Mato et al. 1988, Caboni et al. 1997, Gaspar et al. 1997) and shoot proliferation (Jones 1976, Sarkar and Naik 2000) are well known. Less detailed data are available concerning the involvement of phenols in androgenesis (Delalonde et al. 1996) or organogenesis (Lorenzo et al. 2001), but the available information appears to indicate a promoting effect at least in some species. With respect to somatic embryogenesis, previous studies have shown that phenolic compounds are often associated with somatic embryo formation. For instance, for coffee explants, it was observed that embryogenic calli developed only after browning of the initial explant (Neuenschwander and Baumann 1992), a necrosis-like process which does not impair somatic embryo formation. Similar observations have been made during somatic embryogenesis induction in other woody species (Radojevic 1979, Tulecke and McGranahan 1985, Anthony et al. 2004). These results demonstrate that somatic embryogenesis induction is not incompatible with phenolic compound production during in vitro culture. More detailed studies of the role of phenolics during somatic embryogenesis induction have been performed by Alemanno et al. (2003) and Ndoumou et al. (1997) in Theobroma cacao and by Cvikrová and co-workers in alfalfa (Cvikrová et al. 1996) and sessile oak (Cvikrová et al. 2003). Ndoumou et al. (1997) found that the differentiation of somatic embryos in cacao is concomitant with a decrease in phenolic content and an increase in the activity of indole- 3-acetic acid-oxidase. Further studies of the same species detected the production of hydroxycinnamic amides in embryogenic calli which were not present in the initial explants (Alemanno et al. 2003). Experiments carried out with sessile oak indicated that the reduction of cinnamic acids stimulates the formation of early stages of somatic embryos (Cvikrová et al. 2003), whereas the same group observed an increase in cell wall-bound phenolic acids in embryogenic cells of alfalfa compared with nonembryogenic calli (Cvikrová et al. 1996). It is not yet clear how phenolic compounds affect somatic embryogenesis induction and somatic embryo development. A possible interference of phenolic compounds with auxin metabolism and, as a consequence, with the levels of this type of plant growth regulator in the explants has been suggested by some authors (Gross et al. 1977, Pressey 1990). It can be hypothesized that these phenolics could also interfere with auxin metabolism in feijoa, keeping auxin at concentrations particularly favourable for somatic embryogenesis induction. However, this must be confirmed by auxin quantification during the embryogenic process.

In our experiments, we found that the inclusion of phloroglucinol and caffeic acid at specific concentrations in the induction medium increased the levels of somatic embryogenesis induction. At present, it is unclear how these phenolic compounds promote somatic embryogenesis. It is possible that some of the phenolic compounds produced in the presence of phloroglucinol and caffeic acid could promote somatic embryogenesis. HPLC analysis showed that these phenolic compounds were mainly gallic acid derivatives, flavan-3-ols, flavanones, and/or dihydroflavonols. As far as we know, none of these compounds have been reported to promote somatic embryogenesis or other types of in vitro morphogenesis. Flavan3-ols and gallic acid derivatives are frequently considered to exhibit antioxidant activities (Wang et al. 1997). The synthesis of phenolic compounds as a consequence of the stress induced by tissue culture conditions has been shown by other authors (Alemanno et al. 2003). However, as pointed out by Alemanno et al. (2003), it must be determined whether the synthesis of these phenols is directly related to somatic embryogenesis induction or is simply a response to stress conditions occurring in vitro. In fact, it is known that in some species, such as Arabidopsis thaliana, stress conditions can enhance somatic embryogenesis induction (Ikeda-Iwai et al. 2003). Taken together, these results seem to indicate that, in certain species, phenolic compounds produced as a response of explants to stress conditions can create a chemical environment appropriate for somatic embryo formation and development, 
probably as a consequence of their antioxidant properties. However, more detailed studies are necessary to confirm this relationship and, in particular, to determine the activity of key enzymes of phenol metabolism, such as phenylalanine ammonia lyase and polyphenol oxidase, and to evaluate the role of the identified phenols in somatic embryogenesis induction.

Inhibition of somatic embryo development beyond the globular stage was observed for all the phenolics tested. However, phloridzin was particularly inhibitory, since somatic embryos formed in the presence of this compound were unable to reach more advanced stages of development even at lower concentrations $(11.5 \mu \mathrm{M})$. A similar effect for phloroglucinol and caffeic acid was only detected at higher concentrations (197.5 and $140.0 \mu \mathrm{M}$, respectively). It is possible that the inhibitory effect of phloridzin on sucrose absorption and transport (Eksittikul et al. 2001) could explain the arrested somatic embryo development, as well as the reduced levels of induction observed in the presence of higher concentrations $(>115 \mu \mathrm{M})$ of this compound. Somatic embryos formed in the presence of this phenolic compound may not have the appropriate amounts of sucrose necessary for basic metabolic activities and therefore become arrested at the globular stage or even at earlier stages of embryo development. However, it should be pointed out that the inhibitory effects could be the simple result of protein precipitation, enzyme inactivation, or membrane damage due to high phenol dosages (Dey et al. 1997). Ultrastructural studies performed on explants cultured in the presence of such high phenol concentrations did not show any signs of membrane damage or organelle modifications when compared with explants cultured in the control (data not presented), but the possibility that the other effects occur must not be ruled out.

A role for phenolic compounds during somatic embryo germination is supported by this study, since we found that exogenous phenols promote not only somatic embryogenesis induction but also somatic embryo germination, phloroglucinol being the most effective in this process. Furthermore, we found that, in the presence of phloroglucinol, the levels of total endogenous phenols attained a peak by the time the first somatic embryos reached the globular stage (third week of culture) and were maintained at levels higher than those in explants cultured in the control or in the presence of caffeic acid. The positive effect of phloroglucinol on in vitro morphogenic processes is well known (Jones 1976, Sarkar and Naik 2000), although the exact role of this compound in promoting somatic embryo germination needs further evaluation.
Previous experiments carried out with feijoa showed a strong association between developing somatic embryos and phenolic-rich cells (Canhoto and Cruz 1996b). Further studies performed in the same species but in another type of embryogenic tissue also detected this relationship (Cangahuala-Inocente et al. 2004). A similar association was also found in other woody plants, such as Ceratonia siliqua (Canhoto et al. 2006), Myrtus communis (Canhoto et al. 1999b), and Tilia cordata (Kärkönen 2000). In the present work, a separation zone was observed that progressively isolated the embryo from the mother tissue. This formed a barrier that, due to the absence of plasmodesmata in its cells and the thickness of the cell walls, probably physiologically isolates the embryo from the mother tissue at a certain stage of development. Ultrastructural studies revealed that cells of this zone show signs of degeneration, possessing vacuoles filled with phenolic compounds and a cytoplasm where microbodies are common. It is possible that cells of this zone undergo a process of programmed cell death necessary for the separation of the embryo from the explant. Mechanisms of programmed cell death are well documented during somatic embryo development of Picea abies and they may also occur in other systems (Bozhkov et al. 2005).

This work is a first approach to understanding the role of phenolic compounds in somatic embryogenesis induction in feijoa. The results obtained so far are promising but we are still far from understanding how phenolic compounds influence somatic embryogenesis. From these results, we can hypothesise that phenols affect somatic embryogenesis in feijoa on at least three different levels: somatic embryogenesis induction, somatic embryo development and germination, and somatic embryo isolation from the mother tissues through the formation of a separation zone of phenolic-rich cells.

\section{Acknowledgments}

This work was supported by the FCT (Fundação para a Ciência e Tecnologia).

\section{References}

Alemanno L, Ramos T, Gargadenec A, Andary C, Ferriere N (2003) Localization and identification of phenolic compounds in Theobroma cacao L. somatic embryogenesis. Ann Bot 92: 613-623

Anthony JM, Senaratna T, Dixon KW, Sivasithamparam K (2004) The role of antioxidants for initiation of somatic embryos with Conostephium pendulum Benth (Ericaceae). Plant Cell Tissue Organ Cult 78: 247-252

Arezki O, Boxus P, Kevers C, Gaspar T (2001) Changes in peroxidase activity, and level of phenolic compounds during light-induced plant- 
let regeneration from Eucalyptus camaldulensis Dehn nodes in vitro. Plant Growth Regul 33: 215-219

Benson EE (2000) In vitro plant recalcitrance: an introduction. In Vitro Cell Dev Biol 36: 141-148

Berthon JY, Battraw MY, Gaspar T, Boyer N (1993) Early test using phenolic compounds and peroxidase activity to improve in vitro rooting of Sequoiadendron giganteum (Lindl) Buchholz. Saussurea 24: $7-13$

Bozhkov PV, Filonova LH, Suarez MF (2005) Programmed cell death in plant embryogenesis. Curr Top Dev Biol 67: 135-181

Caboni E, Tonelli MG, Lauri P, Iacovacci P, Kevers C, Damiano C, Gaspar T (1997) Biochemical aspects of almond microcuttings related to in vitro rooting ability. Biol Plant 39: 91-97

Cangahuala-Inocente GC, Steiner N, Santos M, Guerra MP (2004) Morphohistological analysis and histochemistry of Feijoa sellowiana somatic embryogenesis. Protoplasma 224: 33-40

Canhoto JM, Cruz GS (1994) Improvement of somatic embryogenesis in Feijoa sellowiana Berg. (Myrtaceae) by manipulation of culture media composition. In Vitro Cell Dev Biol 30: 21-25

Canhoto JM, Cruz GS (1996a) Feijoa sellowiana Berg (pineapple guava). In: Bajaj YPS (ed) Trees IV. Biotechnology in agriculture and forestry, vol 35. Springer, Berlin, pp 155-171

Canhoto JM, Cruz GS (1996b) Histodifferentiation of somatic embryos in cotyledons of pineapple guava (Feijoa sellowiana Berg). Protoplasma 191: 34-45

Canhoto JM, Mesquita JF, Cruz GS (1996) Ultrastructural changes in cotyledons of pineapple guava (Myrtaceae) during somatic embryogenesis. Ann Bot 78: 513-521

Canhoto JM, Lopes ML, Cruz GS (1999a) Somatic embryogenesis in myrtaceous plants. In: Jain SM, Gupta PK, Newton RJ (eds) Somatic embryogenesis in woody plants, vol 4. Kluwer Academic, Dordrecht, pp 293-340

Canhoto JM, Lopes ML, Cruz GS (1999b) Somatic embryogenesis and plant regeneration in myrtle (Myrtaceae). Plant Cell Tissue Organ Cult 57:13-21

Canhoto JM, Lopes ML, Cruz GS (1999c) Somatic embryogenesis in bay laurel (Laurus nobilis L). In: Jain SM, Gupta PK, Newton RJ (eds) Somatic embryogenesis in woody plants, vol 4. Kluwer Academic, Dordrecht, pp 341-367

Canhoto JM, Rama S, Cruz GS (2006) Somatic embryogenesis and plant regeneration in carob (Ceratonia siliqua L.). In Vitro Cell Dev Biol 42: 514-519

Cruz GS, Canhoto JM, Abreu MA (1990) Somatic embryogenesis and plant regeneration from zygotic embryos of Feijoa sellowiana Berg. Plant Sci 66: 263-270

Cvikrová M, Hrubcová M (1999) The role of phenolic substances in the processes of differentiation and morphogenesis. In: Strnad M, Pĕc P, Beck E (eds) Advances in regulation of plant development. Peres Publications, Prague, pp 213-220

Cvikrová M, Hrubcová M, Eder J, Binarová P (1996) Changes in the levels of endogenous phenolics, aromatic monoamines, phenylalanine ammonia-lyase, peroxidase and auxin oxidase activities during initiation of alfalfa embryogenic and nonembryogenic calli. Plant Physiol Biochem 34: 853-861

Cvikrová M, Malá J, Eder J, Hrubcová M, Vágner M (1998) Abscisic acid, polyamines and phenolic acids in sessile oak somatic embryos in relation to their conversion potential. Plant Physiol Biochem 36: 247-255

Cvikrová M, Malá J, Hrubcová M, Eder J, Zón J, Macácková I (2003) Effect of inhibition of biosynthesis of phenylpropanoids on sessile oak somatic embryogenesis. Plant Physiol Biochem 41: 251-259

Dal Vesco LL, Guerra MP (2001) The effectiveness of nitrogen sources in feijoa somatic embryogenesis. Plant Cell Tissue Organ Cult 64: $19-25$
Delalonde M, Barret Y, Coumans MP (1996) Development of phenolic compounds in maize anthers (Zea mays) during cold pre-treatment prior to androgenesis. J Plant Physiol 149: 612-616

Dey PM, Brownleader MD, Harborne JB (1997) The plant, the cell and its molecular component. In: Dey PM, Harborne JB (eds) Plant biochemistry. Academic Press, San Diego, pp 1-47

Eksittikul T, Chulavatnatol M, Limpaseni T (2001) Characterization of sucrose uptake system in cassava (Manihot esculenta Crantz). Plant Sci 160: 733-737

Folin O, Ciocalteu V (1927) On tyrosine and tryptophane determinations in proteins. J Biol Chem 27: 239-343

Gaspar T, Kevers C, Hausman JF (1997) Indissociable chief factors in the inductive phase of adventitious rooting. In: Altman A, Waisel Y (eds) Biology of root formation and development. Plenum, New York, pp 55-63

Gross GG, Janse C, Elstner EF (1977) Involvement of malate, monophenols, and the superoxide radical in hydrogen peroxide formation by isolated cell walls from horseradish (Armoraciala pathifolia Gilib). Planta 136: 271-276

Hanower J, Hanower P (1984) Inhibition et stimulation en culture in vitro de l'embryogénèse des souches issues d'explant foliaires de palmier à l'huile. C R Acad Sci Paris 298: 45-48

Harborne JB (1998) Phytochemical methods: a guide to modern techniques of plant analysis, 3rd edn. Chapman and Hall, London, pp 40-106

Ikeda-Iwai M, Umehara M, Satoh S, Kamada H (2003) Stress-induced somatic embryogenesis in vegetative tissues of Arabidopsis thaliana. Plant J 34: 107-114

Jones OP (1976) Effect of phloridzin and phloroglucinol on apple shoots. Nature 262: 392-393

Kärkönen A (2000) Anatomical study of zygotic and somatic embryos of Tilia cordata. Plant Cell Tissue Organ Cult 61: 205-214

Lee TT, Skoog F (1965) Effects of substituted phenols on bud formation and growth of tobacco tissue cultures. Physiol Plant 18: 386-402

Lorenzo JC, Blanco MA, Peláez O, González A, Cid M, Iglesias A, González B, Escalona M, Espinosa P, Borroto C (2001) Sugarcane micropropagation and phenolic excretion. Plant Cell Tissue Organ Cult 65: $1-8$

Martin KP, Madassery J (2005) Direct and indirect somatic embryogenesis on cotyledon explants of Quassia amara L., an antileukaemia drug plant. In Vitro Cell Dev Biol 41: 54-57

Mato MC, Rúa MI, Ferro E (1988) Changes in levels of peroxidases and phenolics during root formation in Vitis cultured in vitro. Physiol Plant 72: 84-88

Muralidharan EM, Mascarenhas AF (1995) Somatic embryogenesis in Eucalyptus. In: Jain SM, Gupta PK, Newton RJ (eds) Somatic embryogenesis in woody plants, vol 2. Kluwer Academic, Dordrecht, pp 23-40

Murashige T, Skoog F (1962) A revised medium for rapid growth and bioassays with tobacco tissue cultures. Physiol Plant 15: 473-497

Ndoumou DO, Ndzomo GT, Niemenak N (1997) Phenol content, acidic peroxidase and IAA-oxidase during somatic embryogenesis in Theobroma cacao L. Biol Plant 39: 337-347

Neuenschwander B, Baumann TW (1992) A novel type of somatic embryogenesis in Coffea arabica. Plant Cell Rep 10: 608-612

Pan MJ, van Staden F (1998) The use of charcoal in in vitro culture - a review. Plant Growth Regul 26: 155-163

Pressey R (1990) Anions activate the oxidation of indoleacetic acid by peroxidases from tomato and other sources. Plant Physiol 93: 798-804

Radojevic L (1979) Somatic embryogenesis and plantlets from callus cultures of Paulownia tomentosa Stued. Z Pflanzenphysiol 91: 57-62

Ramírez-Malagón R, Borodanenko A, Barrera-Guerra JL, Ochoa-Alejo N (1997) Micropropagation for fraser photinia (Photinia $\times$ fraseri). Plant Cell Tissue Organ Cult 48: 219-222 
Sarkar D, Naik PS (2000) Phloroglucinol enhances growth and rate of axillary shoot proliferation in potato shoot tip cultures in vitro. Plant Cell Tissue Organ Cult 60: 139-149

Stefanello S, Dal Vesco LL, Ducroquet JP, Nodari RO, Guerra MP (2005) Somatic embryogenesis from floral tissues of feijoa (Feijoa sellowiana Berg). Sci Hortic 105: 117-126

Tang W, Newton RJ (2004) Increase of polyphenol oxidase and decrease of polyamines correlate with tissue browning in Virgin pine (Pinus virginiana Mill.). Plant Sci 167: 621-628

Thorpe TA, Stasolla C (2001) Somatic embryogenesis. In: Bhojwani SS, Soh WY (eds) Current trends in the embryology of angiosperms. Kluwer Academic, Dordrecht, pp 279-336

Tulecke W, McGranahan G (1985) Somatic embryogenesis and plant regeneration from cotyledon tissue of walnut, Juglans regia L. Plant Sci 40: $53-67$ von Arnold S, Sabala I, Bozhkov P, Dyachok J, Filonova L (2002) Developmental pathways of somatic embryogenesis. Plant Cell Tissue Organ Cult 69: 233-249

Wang C-K, Lee W-H, Peng C-H (1997) Contents of phenolics and alkaloids in Areca catechu Linn. during maturation. J Agric Food Chem 45: 1185-1188

Warrag EI, Lesney MS, Rockwood DL (1990) Micropropagation of field tested superior Eucalyptus grandis hybrids. New Forests 4: 67-79

Watt MP, Blakeway FC, Termignoni R, Jain SM (1999) Somatic embryogenesis in Eucalyptus grandis and E. dunni. In: Jain SM, Gupta PK, Newton RJ (eds) Somatic embryogenesis in woody plants, vol 5. Kluwer Academic, Dordrecht, pp 63-78

Zar JH (1996) Biostatistical analysis, 3rd edn. Prentice Hall, Upper Saddle River, NJ 